\title{
Arsenic, cadmium and lead concentrations in Yerba mate commercialized in Southern Brazil by inductively coupled plasma mass spectrometry
}

\author{
Lisia Maria Gobbo dos Santos ${ }^{1 *}$ Santos Alves Vicentini Neto ${ }^{1}$ \\ Giovanna Iozzi $^{1}$ Silvana do Couto Jacob ${ }^{1}$
}

'Departamento Química, Instituto Nacional de Controle de Qualidade em Saúde (INCQS/Fiocruz), 21040-900, Rio de Janeiro, RJ, Brasil. E-mail: lisia.gobbo@incqs.fiocruz.br. "Corresponding author.

\begin{abstract}
Mate" or "Yerba Mate" (Ilex paraguariensis) is a native South American plant, commonly consumed in Argentina, Paraguay, Uruguay and southern Brazil. Recent research has detected the presence of many vitamins and metals in this plant. Theses-metals are also part of yerba mate's mineral composition, due to soil and water contamination by pesticides and fertilizers, coal and oil combustion, vehicle emissions, mining, smelting, refining and the incineration of urban and industrial waste. Regardless of their origin, some inorganic elements, such as arsenic, cadmium and lead, are considered toxic, since they accumulate in all plant tissues and are, thus, introduced into the food chain. In this context, the aim of the present study was to determine and compare arsenic, cadmium, lead concentrations in 104 samples of yerba mate (Ilex paraguariensis) marketed, and consumed in three southern Brazilian States, namely Paraná (PR), Santa Catarina (SC) and Rio Grande do Sul (RS). Each element was determined by inductively coupled plasma mass spectrometry (ICP-MS), on a Nexion 300D equipment (Perkin Elmer). As, Cd and Pb concentrations in yerba mate leaves ranged from 0.015 to $0.15 \mathrm{mg} \mathrm{kg}^{-1}, 0.18$ to $1.25 \mathrm{mg} \mathrm{kg}^{-1}$ and 0.1 to $1.20 \mathrm{mg} \mathrm{kg}$, respectively. Regarding $C d, 84 \%$ of the samples from $R S, 63 \%$ from $P R$ and $75 \%$ from SC showed higher concentrations than the maximum permissible limit of $0.4 \mathrm{mg} \mathrm{kg-1}$ established by the Brazilian National Sanitary Surveillance Agency (ANVISA), while 7\% of the samples from RS and $5 \%$ from $P R$ were unsatisfactory for Pb. Concentrations were below the established ANVISA limit of $0.6 \mathrm{mg} \mathrm{kg}^{-1}$ for all samples.
\end{abstract} Key words: arsenic, cadmium, lead, ICP-MS, Yerba mate.

Determinação da concentração de arsênio, cádmio e chumbo em amostras de erva-mate comercializadas no Sul do País por espectrometria de massa com plasma indutivamente acoplado

RESUMO: A erva-mate (Ilex paraguariensis) é uma planta originária da América do Sul, consumida habitualmente na Argentina, Paraguai, Uruguai e no sul do Brasil. Pesquisas, recentes, detectaram na erva-mate a presença de muitas vitaminas e metais. Esses metais podem fazer parte da composição mineral da planta ou por contaminação dos solos e águas pelo uso de fertilizantes, pesticidas, combustão de carvão e óleo, emissões veiculares, mineração, fundição, refinamento e incineração de resíduos urbanos e industriais. Independente da sua origem, os metais são acumulados em todos os tecidos das plantas, sendo desta forma introduzidos na cadeia alimentar. Alguns desses elementos inorgânicos são considerados tóxicos, como arsênico, cádmio e chumbo. O objetivo deste trabalho foi determinar e comparar as concentrações de metais na erva-mate (Ilex paraguariensis) comercializadas e consumidas nos diferentes estados do sul do Brasil. 104 amostras foram coletadas em supermercados no sul do Brasil: Paraná (PR), Santa Catarina (SC) e Rio Grande do Sul (RS). A determinação da concentração de As, Cd, Pb foi feita por espectrometria de massa por plasma indutivamente acoplado (ICP-MS), modelo Nexion 300D (Perkin Elmer). As concentrações de $\mathrm{As}$, Cd e Pb em folhas de erva-mate variaram de 0,015-0,15mg kg-1; 0,18-1,25mg $\mathrm{kg}^{-1}$ e 0,1-1,20mg $\mathrm{kg}^{-1}$. 84\% do RS, 63\% do PR e 75\% do SC, a concentração de Cd na erva mate foi superior ao limite estabelecido $\left(0,4 m g \mathrm{~kg}^{-1}\right)$, pela Agência Nacional de Vigilância Sanitária (ANVISA), 7\% do RS, 5\% do PR foram insatisfatórias para Pb e a concentração de As ficou abaixo do limite estabelecido (0,6mg $\mathrm{kg}^{-1}$ ).

Palavras-chave: arsênio, cádmio, chumbo, ICP-MS, erva-mate.

\section{INTRODUCTION}

Yerba Mate (Ilex paraguariensis) is a native South American plant, commonly consumed in Argentina, Paraguay, Uruguay and southern Brazil. Both its leaves and branches are marketed; the former can be used for tonic drinks and stimulants made by hot infusion of eaves, such as "chimarrão", or cold infusions, such as "tererê". Yerba leaves are also used toasted for the preparation of "mate tea", as well as pharmaceutical formulations (ALBAS et al., 2014).

This plant has increasingly drawn the attention of the scientific community, since its beneficial effects are also associated with therapeutic effects, such as anti-oxidant, diuretic, stimulant, laxative and anti-rheumatic effects, as well as digestive 
properties (FILIP \& FERRARO, 2003; SAIDELLES et al., 2010). Conversely, the incidence of esophageal cancer is significant in areas where people consume yerba mate in the form of "chimarrão".

Some studies suggested that the ingestion of yerba mate infusions at high temperatures, above $60^{\circ} \mathrm{C}$, is the only risk factor; while other support the hypothesis that the risk of cancer is associated with the level of certain substances present in the infusions that exhibit carcinogenic potential or potentiate the action of lesions caused by the frequent consumption of large volumes of "chimarrão", whose average consumption per capita is $1.265 \mathrm{~L} \mathrm{day}^{-1}$ in certain regions, reaching up to $6 \mathrm{~L} \mathrm{day}^{-1}$ (BARROS et al., 2000).

The International Agency for Research on Cancer (IARC) assessed the carcinogenic risk of mate and concluded that the yerba mate hot infusions act as a "probable carcinogen" to humans (Group 2A) and that the herb itself is non-classifiable as to its carcinogenicity to humans (Group 3) (IARC, 1991). However, its carcinogenic, chemical and thermal mechanisms should be investigated (GOLDENBERG et al., 2003; ALBAS et al., 2014)

Recent investigations have detected the presence of metals in yerba mate, (VULCANO et al., 2008; SAIDELLES et al., 2010). due to soil and water contamination by the use of fertilizers, agrochemicals, coal and oil combustion, vehicular emissions, mining, smelting, refining and incineration of urban and industrial waste. Regardless of their origin, metals are accumulated in all plant tissues and are, thus, introduced into the food chain (ERNST, 2002; SAIDELLES, et al., 2013).

Many of these metals are considered essential for the development of plants, animals and humans, while others are potentially toxic, such as arsenic, cadmium and lead (SAIDELLES et al., 2010). This toxicity depends mainly on the form of the metal and its concentration in the ingested foodstuff, although exposure period and frequency must also be considered.

When absorbed, arsenic is stored in the liver, kidneys, heart, and lungs. A small part remains in muscle and nervous tissues, and its accumulation has been associated with several diseases, such as cancer, diabetes, hepatotoxicity, neurotoxicity and cardiac dysfunction (SINGH et al, 2011). Other symptoms of As intoxication include abdominal pain, vomiting, diarrhea, blood in urine, seizures, coma and death, which can be confused with diseases such as cholera and pneumonia (HUGHES, 2011; TELLEZ-PLAZA, 2012).
Cadmium is widely absorbed and distributed throughout plants, present in leaves, fruits and seeds (MORAIS et al., 2012). Cadmium intoxication is associated with the prevalence of hepatic, cardiovascular and central nervous system diseases, renal deficiency and breast cancer, hematological and immunological effects, as well as reproductive and embryonic developmental deficiencies (TELLEZ-PLAZA et al., 2012).

Lead is the most common environmental contaminant, distributed throughout the planet in the form of salts, metal alloys and inorganic ions (POLETTI et al., 2014). Food is the main source of exposure to lead, followed by water ingestion (MORAIS et al., 2012). Lead has no biological function and is associated with chronic anemia due to inhibition of the enzyme that catalyzes an essential step in hemoglobin production (FRANCO et al., 2011). Lead poisoning is also associated with nephrotoxicity and neurotoxicity, resulting in reduced central nervous system development, especially in children (MORAIS et al., 2012,).

Recent reports of cadmium and lead contamination in mate have been of great concern to producers and beneficiaries, due to possible losses to the sector. The ANVISA Resolution RDC No. 42 of August 29, 2013, which internalizes the MERCOSUL Technical Regulation on Maximum Limits of Inorganic Contaminants in Food in Brazil, recommends the following maximum limits in teas, herbs and other vegetables used for infusions: Arsenic $0.6 \mathrm{mg} \mathrm{kg}^{-1}$, cadmium $0.4 \mathrm{mg} \mathrm{kg}^{-1}$ and for lead $0.6 \mathrm{mg} \mathrm{kg}^{-1}$.

In view of the growing market for natural products with functional properties and lack of quality standardization for these goods, including mate, studies on possible contamination by metals will contribute to product quality and safety, aiming to add values to the domestic and international markets. In view of this, it is imperative to control the quality of plants used for medicinal and nutritional purposes, such as yerba mate. In this context, the aim of the present study was to determine and compare arsenic, cadmium and lead concentrations in Ilex paraguariensis samples marketed and consumed in the Southern region of Brazil, in the states of Paraná (PR), Santa Catarina and Rio Grande do Sul (RS). In order to evaluate the possible danger of ingestion, infusions prepared with the analyzed samples were also evaluated.

\section{MATERIALS AND METHODS}

Yerba mate samples were collected by the State Sanitary Surveillance Secretaries in 
commercial establishments located in different cities in the states of Paraná, Santa Catarina and Rio Grande do Sul.

Inclusion criterion concerned 106 brands actually and registered in the labor unions of RS, SC and PR. A total of 104 samples representing 73 different brands were sent for analyses: 77 (49 brands) from RS, 11 (8 brands) from $\mathrm{SC}$ and 16 (16 brands) from PR. The chemical analyses were carried out in the Inorganic Elements Sector of the Chemistry Department of the National Institute of Quality Control in Health (INCQS), at the Oswaldo Cruz Foundation (FIOCRUZ).

Samples were homogenized, ground in an industrial type crusher and stored in suitable containers. Approximately $0.5 \mathrm{~g}$ of each sample, in duplicate, were weighed into Teflon tubes and $2 \mathrm{~mL}$ of deionized water (Millipore, Brazil) were added, along with $2 \mathrm{~mL}$ of supercritical nitric acid (Merck, Germany) and $2 \mathrm{~mL}$ of hydrogen peroxide (Merck, Germany). Samples were then digested in a high pressure closed system in a SpeedWave microwave (Berghof, Germany). After cooling, the sample solutions were transferred to $25 \mathrm{~mL}$ volumetric flasks and completed with ultrapure water.

\section{Infusions}

Sample infusions were prepared following a protocol developed in the Inorganic Elements Sector (DQ/INCQS/FIOCRUZ) based on SAIDELLES et al. (2013) and HEINRICHS \& MALAVOLTA (2001).

Approximately $1.5 \mathrm{~g}$ of each sample were weighed and immersed in $10 \mathrm{~mL}$ of deionized water previously heated at $80^{\circ} \mathrm{C}$. Samples were left at that temperature for 5 minutes and then centrifuged. As the samples absorbed a significant amount of water, after the process the extracted analyte was not available in $10 \mathrm{~mL}$ but instead, in the supernatant volume.

The first volumes, named supernatant 1 , were collected, filtered, stored in polyethylene bottles and used in concentration calculations.
Subsequent infusions with the same solid extract from the sample were prepared in the same procedure, left at temperature $80^{\circ} \mathrm{C}$ for 5 minutes and after centrifuged. Supernatants (supernatant 2) were also removed, filtered and also stored in polyethylene bottles. The two infusions (supernatant 1 and supernatant 2) were diluted twice after adding rhodium as an internal standard and analyzed. This procedure was performed in an attempt to reproduce the preparation of the "chimarrão" beverage by users.

Instrumentation

All experiments were performed on an inductively coupled plasma mass spectrometer (ICPMS) (NexION 300D, PerkinElmer, USA) equipped with a concentric nebulizer (Meinhard), cyclonic glass nebulizer, cone, skimmer and nickel hyperskimmer. The equipment was operated in standard mode, with $15 \mathrm{~ms}$ dwell time, 50 scans per read and one read per replicate, totaling three replicates. Argon gas with a minimum purity of $99.996 \%$ (White Martins, São Paulo, Brazil). Airflows were maintained at the following conditions: main $17 \mathrm{~L}$ $\mathrm{min}^{-1}$, intermediate $1.1 \mathrm{~L} \mathrm{~min}^{-1}$ and nebulizer $1 \mathrm{~L} \mathrm{~min}^{-1}$, with radio frequency power at $1400 \mathrm{~W}$. Ten $\mu \mathrm{g} \mathrm{L}^{-1}$ of $\mathrm{Rh}$ were added to the blank, standards and samples solution as internal standard.

The analytical performance of the method was evaluated for each sample batch, through a recovery study. The limits of method detection, relative standard deviations and accuracy of the method for microwave digestion are displayed in table 1 .

\section{RESULTS AND DISCUSSION}

Table 2 displays the $\mathrm{As}, \mathrm{Cd}$ and $\mathrm{Pb}$ concentrations in the mate samples obtained from the three southern Brazilian states. Results were analyzed using descriptive statistic techniques (means, standard deviation and median).

The differences in the metal concentrations from the different states may be associated with

Table 1 - Mass of the evaluated $\mathrm{As}, \mathrm{Cd}$ and $\mathrm{Pb}$ isotopes and their limits of detection, relative standard deviations and recovery, using $\mathrm{Rh}$ as internal standard.

\begin{tabular}{lcccc}
\hline & Isotope mass (u.m.a.) & Limit of detection $\left(\mathrm{ng} \mathrm{L}^{-1}\right)$ & $\mathrm{RSD}(\mathrm{n}=5)$ & Recovery \\
$\mathrm{As}$ & 75 & 5.5 & $1.8 \%$ & $104 \%$ \\
$\mathrm{Cd}$ & 111 & 4.9 & $2.0 \%$ & $109 \%$ \\
$\mathrm{~Pb}$ & 208 & 43 & $1.6 \%$ & $114 \%$ \\
\hline
\end{tabular}


Table 2 - Concentrations of $\mathrm{As}, \mathrm{Cd}$ and $\mathrm{Pb}$ in the mate samples obtained from the three Southern Brazilian states.

\begin{tabular}{|c|c|c|c|c|c|}
\hline \multirow{2}{*}{ State } & \multirow{2}{*}{$\mathrm{N}$} & & & Anal & \\
\hline & & & As & $\mathrm{Cd}$ & $\mathrm{Pb}$ \\
\hline \multirow{4}{*}{ Rio Grande do Sul } & \multirow{4}{*}{77} & Means \pm SD & $0.03 \pm 0.01$ & $0.59 \pm 0.20$ & $0.41 \pm 0.23$ \\
\hline & & Median & 0.029 & 0.60 & 0.4 \\
\hline & & Variation & $0.015-0.033$ & $0.18-1.25$ & $0.10-1.20$ \\
\hline & & $\%$ RSD & 46 & 40 & 49 \\
\hline \multirow{4}{*}{ Santa Catarina } & \multirow{4}{*}{11} & Means \pm SD & $0.06 \pm 0.03$ & $0.42 \pm 0.19$ & $0.29 \pm 0.09$ \\
\hline & & Median & 0.06 & 0.49 & 0.34 \\
\hline & & Variation & $0.015-0.114$ & $0.25-0.71$ & $0.20-0.54$ \\
\hline & & $\%$ RSD & 65 & 46 & 33 \\
\hline \multirow{4}{*}{ Paraná } & \multirow{4}{*}{16} & Means \pm SD & $0.056 \pm 0.03$ & $0.47 \pm 0.15$ & $0.44 \pm 0.10$ \\
\hline & & Median & 0.056 & 0.45 & 0.38 \\
\hline & & Variation & $0.015-0.15$ & $0.21-0.72$ & $0.25-0.70$ \\
\hline & & $\%$ RSD & 73 & 32 & 33 \\
\hline
\end{tabular}

different soil chemical characteristics of each state, as well as plant genetics and age (SAIDELLES et al., 2010). As concentrations present in the yerba mate samples ranged from 0.015 to $0.114 \mathrm{mg} \mathrm{kg}^{-1}$. Thus, $100 \%$ of the samples displayed As levels below the maximum limit allowed by the current Brazilian legislation, of $0.6 \mathrm{mg} \mathrm{kg}^{-1}$.

The lowest $\mathrm{Pb}$ concentration was $0.10 \mathrm{mg}$ $\mathrm{kg}^{-1}$, and the highest, $1.20 \mathrm{mg} \mathrm{kg}^{-1}$, with $7 \%$ of the samples presenting values above the maximum permitted limit of $0.6 \mathrm{mg} \mathrm{kg}^{-1}$. The highest levels of $\mathrm{Pb}$ contamination were observed in samples from RS, five samples, followed by PR, three samples, and $\mathrm{SC}$, in which no samples exhibited $\mathrm{Pb}$ concentrations above the maximum permissible limit. A comparative analysis (ANOVA) of the $\mathrm{Pb}$ means from the samples originated from the different Brazilian states indicated that SC presented significantly different means from RS and PR. In the study by SAIDELLES et al. (2010), $\mathrm{Pb}$ concentrations in yerba mate were $<0.3 \mathrm{mg} \mathrm{kg}^{-1}$, a result comparable to the results reported herein. The mean $\mathrm{Pb}$ concentrations in virgin and fertilized soil in the Rio Grande do Sul region have been reported as ranging from 8.23 to $16.38 \mathrm{mg} \mathrm{kg}^{-1}$, respectively, while soil samples from $\mathrm{SC}$ and $\mathrm{PR}$ showed no variation between soil types and $\mathrm{Pb}$ concentrations ranged from 16.38 to $34.20 \mathrm{mg} \mathrm{kg}^{-1}$ (POLLETI et al., 2014). Establishment of a direct relationship between $\mathrm{Pb}$ levels in soils reported by POLLETTI et al. (2014) and those reported herein was not possible, and statistical similarities were reported only between RS and PR.
$\mathrm{Cd}$ concentrations in the 104 analyzed samples ranged from 0.18 to $1.25 \mathrm{mg} \mathrm{kg}^{-1}$, with $74 \%$ of the total samples exhibiting $\mathrm{Cd}$ levels above the maximum permissible limit allowed by the Brazilian legislation, of $0.4 \mathrm{mg} \mathrm{kg}^{-1}$. When separated per state, $84 \%$ of the Rio Grande Sul samples, $63 \%$ of the SC samples and $75 \%$ of the PR samples were above this limit. The mean $\mathrm{Cd}$ concentrations in the samples from the three studied states were not statistically different by an ANOVA test. SAIDELLES et al. (2010) observed Cd concentrations in yerba mate ranging from 0.35 to $1.21 \mathrm{mg} \mathrm{kg}^{-1}$, consistent with the results reported herein, while the $\mathrm{Cd}$ values reported by POLLETI et al. (2014) in soil samples from RS, $\mathrm{SC}$ and PR varied between 1.76 and $3.53 \mathrm{mg} \mathrm{kg}^{-1}$.

The observed Cdconcentrations inyerbamate were the same or above the observed $\mathrm{Pb}$ concentrations, suggesting that $\mathrm{Cd}$ bioavailability in Ilex paraguariensis is much higher than $\mathrm{Pb}$ bioavailability in the cultivation conditions where the samples were grown, leading to higher $\mathrm{Cd}$ absorption from the soil. This assumption is based on the results reported by POLLETI et al. (2014), in which mean $\mathrm{Cd}$ concentrations of in the soil is lower than that of $\mathrm{Pb}$ and would result in a plant/soil ratio $20 \%$ for $\mathrm{Cd}$ and less than $5 \%$ for $\mathrm{Pb}$.

The maximum limit recommended by the ANVISA for $\mathrm{Cd}$ in yerba mate is four times higher than the limit recommended by the European Pharmacopoeias, of $0.1 \mathrm{mg} \mathrm{kg}^{-1}$ for leaves, fruits and vegetable roots (DUGO, et al., 2004). If the international limit were to be considered, $100 \%$ of 
the 104 samples analyzed in the present study would present unsatisfactory results, resulting in problems regarding product marketing and export.

With regard to the infusions, the mean values of $\mathrm{Cd}, \mathrm{Pb}$ and $\mathrm{As}$ in the supernatants 1 and 2 were not significantly different $(\mathrm{P}>0.05)$ after a comparative analysis by an ANOVA test. Comparing total sample decomposition with the infusions, $\mathrm{Cd}$ and $\mathrm{Pb}$ were extracted at approximately $10 \%$ and $5 \%$, respectively. It was not possible to quantify how much As was extracted, since the metal was present in the infusions at concentrations lower than the method limit of quantification.

\section{CONCLUSION}

This study was developed with the aim of providing information and subsidizing discussions on arsenic, cadmium and lead concentrations in different yerba matte samples from southern Brazil. About $80 \%$ of the different brands and types of herbs studied were unfit for consumption, due to the high levels of lead and cadmium present, although arsenic concentrations were within the required standards in all samples.

With regard to the metal concentrations in the infusions prepared with the contaminated yerba mate samples, $\mathrm{Cd}$ and $\mathrm{Pb}$ levels were higher in the first infusion, decreasing in the second and-in the following infusions, containing a maximum of $10 \%$ of the total metal concentrations reported in the in natura herbs. Thus, this research indicated that the yerba mate used in the form of hot infusions in Southern Brazilian states exhibits low metal concentrations and more studies are needed to elucidate the risk probability related to consumption of this infusions.

In addition, this research can help the competent organs in an evaluation of the maximum permitted value for these products in the yerba mate and the infusion, since the "chimarrão" is a product that possesses innumerable medicinal properties, generates thousands of direct and indirect jobs and is a symbol of the tradition and of country south culture.

\section{REFERENCES}

ALBAS, C.S et al. Avaliação da genotoxicidade da Ilex paraguariensis (erva mate) pelo teste do micronúcleo. Revista Brasileira de Plantas Medicinais, v.16, n.2, p. 345-349, 2014. Available from: <http://dx.doi.org/10.1590/1983-084X/12_058>. Accessed: Sept. 10, 2016. doi: 10.1590/1983-084X/12 058.

ANVISA(AGÊNCIANACIONALDEVIGILÂNCIASANITÁRIA). Resolution RDC No. 42 of August 29, 2013. Available from: $<\mathrm{http}$ :// portal.anvisa.gov.br>. Accessed: Feb. 04, 2017.
BARROS, S.G.S. et al. High temperature "matè" infusion drinking in a population at risk for squamous cell carcinoma of the esophagus in southern Brazil. Archive Gstroenterol, v.37, n.1, p.25-30, 2000. Available from: <http://dx.doi.org/10.1590/S000428032000000100006>. Accessed: Feb. 15, 2016. doi: 10.1590/ S0004-28032000000100006.

DUGO, G. et al. Determination of $\mathrm{Cd}$ (II), $\mathrm{Cu}$ (II), $\mathrm{Pb}$ (II), and $\mathrm{Zn}$ (II) content in commercial vegetable oils using derivative potentiometric stripping analysis. Food Chemistry, v.87, n.4, p.639-645, 2004. Available from: <http://dx.doi.org/10.1016/j. foodchem.2003.12.035>. Accessed: Feb. 14, 2017. doi. 10.1016/j. foodchem.2003.12.035

ERNST, E. Toxic heavy metals and undeclared drugs in Asian herbal medicines. Trends in Pharmacological Sciences, v.23, n.3 p.136-139, 2002. Avalaible from: <http://dx.doi.org/10.1016/ S0165-6147(00)01972-6>. Accessed: Jan. 04, 2017. doi: 10.1016/ S0165-6147(00)01972-6.

FILIP, R.; FERRARO, G.E. Researching on new species of "Mate": Ilex brevicuspis- photochemical and pharmacology study. European Journal of Nutrition, v.42, n.1, p.50-54, 2003. Available from: <http://dx.doi.org/10.1007/s00394-003-0399-1>. Accessed: Feb. 04, 2017. doi: 10.1007/s00394-003-0399-1.

FRANCO, M.J. et al. Determinação de metais em plantas medicinais comercializadas na região de Umuarama-PR. Arquivo Ciência Saúde UNIPAR, v.15, n.2, p.121-127, 2011. Available from: <http://www.revistas.unipar.br/index.php/saude/ article/viewFile/3706/2406>. Accessed: Feb. 04, 2017.

GOLDENBERG, D. et al. The beverage mate: a risk factor for cancer of the head and neck. Journal of the sciences and specialties of the Head and Neck, v.25, n.7, p.595-601, 2003. Available from: $<$ http://onlinelibrary.wiley.com/doi/10.1002/hed.10288/epdf $>$. Accessed: Sept. 10, 2016. doi: 10.1002/hed.10288.

HEINRICHS, R.; MALAVOLTA, E. Mineral composition of a commercial product from mate-herb (Ilex paraguariensis St. Hil.). Ciência Rural, v.31, n.5, p.781-785, 2001. Available from: <http:// dx.doi.org/10.1590/S0103-84782001000500007>. Accessed: Feb. 14, 2017. doi. 10.1590/S0103-84782001000500007.

HUGHES, M.F. et al. Arsenic exposure and toxicology: a historical perspective. Toxicological Sciences, v.123, n.2, p.305-332, 2011. Available from: <https://doi.org/10.1093/toxsci/kfr184>. Accessed: Jan. 04, 2017. doi: 10.1093/toxsci/kfr184.

INTERNATIONAL AGENCY FOR RESEARCH ON CANCER. Coffee, tea, methylxantines and methylglyoxal. In: IARC Monographs on the evaluation of carcinogenic risks of chemicals to humans. Lyon, 1991. (Scientific Publication 51). Available from: <http://monographs.iarc.fr/ENG/Monographs/ vol51/mono51.pdf>. Accessed: Sept. 10, 2016.

MORAIS, S. et al. Heavy metals and human health. Environmental Health - Emerging Issues and Practice. ISBN: 978-953-307854-0, InTech, 2012. Available from: <http://www.intechopen. com/books/environmental-health-emerging-issues-and-practice/ heavy-metals-and-human-health $>$. Accessed: Jan. 04, 2017. doi: $10.5772 / 29869$.

POLETTI, G.D. et al. Determinação de cádmio e chumbo em solos usados em plantações de erva-mate sem e com diferentes tipos de 
manejo na região sul do país. Revista Destaques Acadêmicos, v.6, n.4, p.59-65, 2014 - CETEC/UNIVATES. Available from: $<$ http://www.univates.br/revistas/index.php/destaques/article/ download/437/429>. Accessed: Feb. 14, 2017.

SAIDELLES, A.P.F. et al. Análise de metais em amostras comerciais de erva-mate do Brasil. Alimentos e Nutrição Araraquara, v.21, n.2, p.259-265, 2010. Available from: <http://serv-bib.fcfar.unesp. br/seer/index.php/alimentos/article/viewFile/996/a12v21n2.pdf>. Accessed: Feb. 15, 2016.

SAIDELLES, A.P.F. et al. Determinação de $\mathrm{Cu}$, Ni e $\mathrm{Zn}$ por ICPMS em infusões da erva-mate comercializadas nas regiões do sul do Brasil. Brazilian Journal of Food and Nutrition, v.24, n.3, p.283-289, 2013. Available from: <http://serv-bib.fcfar.unesp.br/ seer/index.php/alimentos/article/viewFile/291/2160>. Accessed: Feb. 15, 2016.
SINGH, R. et al. Heavy metals and living systems: an overview. Indian Journal Pharmacology, v.43, n.3, p.246-253, 2011. Available from: <https:/www.ncbi.nlm.nih.gov/pmc/articles/ PMC3113373/>. Accessed: Jan. 04, 2017. doi: 10.4103/02537613.81505 .

TELLEZ-PLAZA, M. et al. Cadmium exposure and all-cause and cardiovascular mortality in the U.S. general population. Environmental Health Perspectives, v.120, n.7, p.1017-1022, 2012. Available from: <https://ehp.niehs.nih.gov/1104352/>. Accessed: Jan. 04, 2017. doi: 10.1289/ehp.1104352.

VULCANO, I.R.C. et al. Lead and cadmium levels in tea traded in the metropolitan area of Belo Horizonte. Brazilian Journal of Pharmaceutical Sciences, v.44, n.3, p.425-431, 2008. Available from: <http://www.scielo.br/pdf/rbcf/v44n3/a12v44n3.pdf>. Accessed: Feb. 04, 2017. 